\title{
MENINGKATKAN HASIL BELAJAR BAHASA INGGRIS SISWA KELAS VII-5 MELALUI STRATEGI PEMBELAJARAN PENINGKATAN KEMAMPUAN BERFIKIR DI SMP NEGERI 1 PANCUR BATU PADA TAHUN PELAJARAN 2019/2020
}

\author{
Nursyam Hasyim Br Purba \\ Guru SMP Negeri 1 Pancur Batu \\ nursyamhasyim86@gmail.com
}

\begin{abstract}
Abstrak
Tujuan penelitian ini adalah untuk: Meningkatkan hasil belajar siswa kelas VII-5 melalui Strategi Pembelajaran Peningkatan Kemampuan Berfikir di SMP Negeri 1 Pancur Batu pada tahun Pelajaran 2019/2020. Metode yang digunakan dalam penelitian adalah Metode Penelitian Tindakan Kelas dengan menggunakan 2 siklus. Subjek penelitian ini adalah siswa Kelas VII-5 SMP Negeri 1 Pancur Batu sebanyak 32 orang. Instrumen yang digunakan untuk memperoleh data adalah menggunakan test, angket dan observasi. Rentang nilai untuk tes adalah 1-100. Teknik analisis data yang digunakan adalah menggunakan jumlah nilai rata rata siswa, persentase jumlah siswa yang tuntas dan persentase jumlah siswa yang belum tuntas. Hasil Penelitian ini menunjukkan terdapat peningkatan hasil belajar dengan menerapkan Strategi Pembelajaran Peningkatan Kemampuan Berfikir dengan hasil sebagai berikut: (1) Terdapat peningkatan rata-rata hasil belajar siswa, dimana pada tes awal rata-rata hasil belajar siswa adalah 39, pada siklus I meningkatkan menjadi 67,5 kemudian pada siklus II meningkat lagi menjadi 77,81, (2).Terdapat peningkatan jumlah siswa yang tuntas, dimana pada tes awal jumlah siswa yang tuntas hanya 0\%, meningkat menjadi 75,0\% pada siklus I kemudian meningkat lagi menjadi 87,5\% pada siklus II,(3). Terdapat penurunan jumlah siswa yang tidak tuntas, dimana pada tes awal jumlah siswa yang tidak tuntas mencapai 100\%, pada siklus I menurun menjadi 25,0\% kemudian pada siklus II menurun lagi menjadi 12,5\% dengan kata lain hanya 4 siswa saja yang memperoleh nilai 60 dan selebihnya (28) siswa memperoleh nilai di atas 70.
\end{abstract}

Kata kunci : hasil belajar, strategi pembelajaran, kemampuan berfikir

\begin{abstract}
The aims of this study are: (1) to improve of student achievement on English at class VII-5 through the Increasing of Thinking Ability Learning Strategy. (2) to improve learnimg activity of students. And (3) to improve students understanding and learning on The Increasing of Thinking Ability Learning Strategy. The method of this study is classroom action research by using two cycles. The subject of this study is the students of VII-5 grade SMP Negeri 1 Pancur Batu. There are 32 students. The techniques to collecting data are test, questioner and observation. The range score for test is 1-100. The technique of analysing data is to to count the average of percentage of the students who pass the standard minimal score and yet. The resullt of the study are: (1) There are the The Increasing average of students achivement, where pre-test is 39 at first cycle is The Increasing to 67,5 and the second cycle is The Increasing to 77,81 (2) There are the The Increasing of the amount of students who pass the test, at the pre-test the students who pass the test is 0\%, and the first cycle it tobe $75 \%$ and the second cycle is to be 87,5\%. (3) There are the decreasing of the students who fail the test. At pre-test there $100 \%$ students are fail and at first cycle is decreasing to be $25 \%$ and at second cycle is tobe 12,5\%. On the other hand There are only 4 students who get the score under 70 and 28 students get score more than 70.
\end{abstract}

Keywords : students achievement, english, increasing of thinking ability, learning, strategy 


\section{PENDAHULUAN}

\subsection{Latar Belakang Masalah}

Guru sangat berpengaruh di dalam proses pembelajaran, terutama di dalam mendesain pembelajaran. Desain pembelajaran yang bermutu tidak hanya terletak pada kemampuan guru dalam menyusun rencana pelaksanaan pembelajaran tapi juga terletak pada kemampuan guru dalam menentukan strategi/ metode pembelajaran, penggunaan media pembelajaran dan menciptakan suasana belajar yang dapat menciptakan keinginan siswa untuk mengikuti proses pembelajaran. Apabila seluruh desain pembelajaran yang telah direncanakan dengan baik kemudian diterapkan dalam proses pembelajaran yang bermakna, maka akan dapat menciptakan hasil belajar siswa yang tinggi. Di samping kemampuan guru dalam mendesain pembelajaran dan menerapkannya dalam proses pembelajaran, motivasi siswa untuk mengikuti proses pembelajaran juga sangat mempengaruhi hasil belajar siswa. Hanya dengan minat siswa yang tinggi maka akan dapat menciptakan hasil belajar siswa yang tinggi pula.

Namun kenyataan di lapangann, guru Kelas VII-5 pada pelajaran Bahasa Inggris belum menerapkan strategi pembelajaran yang dapat meningkatkan minat belajar siswa sehingga hasil belajar siswa menjadi rendah. maka dilakukan usaha untuk meningkatkan minat siswa dan hasil belajar siswa melalui cara merubah strategi pembelajaran yang diterapkan di dalam kelas yang selama ini menggunakan strategi pembelajaran konvensional menjadi strategi pembelajaran yang berpusat pada siswa. Oleh sebab itu dibuat penelitian yang berjudul "Meningkatkan hasil belajar Bahasa Inggris siswa di Kelas VII-5 melalui Strategi Pembelajaran Peningkatan Kemampuan Berfikir di SMP Negeri 1 Pancur Batu pada Tahun Pelajaran 2019/2020.

\subsection{Perumusan Masalah}

Berdasarkan identifikasi masalah di atas, maka masalah yang dapat dirumuskan sebagai berikut:

Apakah Strategi Pembelajaran Peningkatan Kemampuan Berfikir dapat meningkatkan hasil belajar siswa pada pelajaran Bahasa Inggris di Kelas VII-5 SMP Negeri 1 Pancur Batu pada Tahun Pelajaran 2019/2020?.

\subsection{Tujuan Penelitian}

Berdasarkan rumusan masalah di atas, maka dapat ditentukan tujuan dalam penelitian ini, yakni:

Untuk meningkatkan hasil belajar siswa pada Pelajaran Bahasa Inggris di Kelas VII-5 SMP Negeri 1 Pancur Batu melalui Strategi Pembelajaran Peningkatan Kemampuan Berfikir pada Tahun pelajaran 2019/2020.

\subsection{Manfaat Penelitian}

Manfaat penelitian ini diharapkan berguna bagi siswa dan guru. Adapun bagi siswa penelitian ini diharapkan:

1. Keaktifan siswa dalam proses pembelajaran meningkat

2. Siswa berani mengemukakan pendapat dengan baik di depan kelas

3. Hasil Belajar Bahasa Inggris semakin meningkat.

Sementara itu bagi guru diharapkan:

Dapat merubah pola mengajar guru dari Strategi Pembelajaran Konvensional menjadi Strategi Pembelajaran Peningkatan Kemampuan Berfikir

\section{METODE}

\subsection{Tempat Dan Waktu Penelitian}

Penelitian ini dilaksanakan pada SMP Negeri 1 Pancur Batu. Jalan Letjen Jamin Ginting Kecamatan Pancur Batu Kabupaten Deli Serdang Provinsi Sumatera Utara. Adapun waktu penelitian ini dilaksanakan selama 6 bulan, yakni mulai dari bulan Juli 2019 sampai Desember 2019. 


\subsection{Subjek Penelitian}

Subjek pada penelitian ini adalah siswa Kelas VII-5 semester 1 (ganjil) Tahun Pelajaran 2019/2020 di SMP Negeri 1 Pancur Batu dengan jumlah siswa sebanyak 32 orang, terdiri dari 17 orang siswa perempuan dan 15 orang siswa lakilaki.

\subsection{Metode Penelitian}

Metode yang digunakan dalam penelitian ini adalah Metode Penelitian Tindakan Kelas dengan menggunakan 2 siklus, dimana tiap-tiap siklus terdiri dari: Perencanaan, pelaksanaan, evaluasi dan refleksi.

\subsection{Desain Prosedur Penelitian}

Prosedur perbaikan pembelajaran yang digunakan adalah prosedur penelitian tindakan kelas dengan alur:

1. Perencanaan, yang meliputi, penetapan RPP, penetapan materi ajar, penetapan strategi pembelajaran, penetapan evaluasi pembelajaran, penetapan waktu pelaksanaan pembelajaran. Standar Kompetensi (SK) yang diajarkan dalam RPP .Penetapan Strategi Pembelajaran menggunakan Strategi Pembelajaran Peningkatan Kemampuan Berfikir (SPPKB)

2. Pelaksanaan tindakan meliputi: pelaksanaan strategi pembelajaran dari awal sampai akhir pembelajaran yang tertuang dalam RPP dimulai dari langkah-langkah pembelajaran dalam strategi pembelajaran PKB

3. Evaluasi, meliputi pelaksanaan evaluasi dari materi pembelajaran yang diajarkan kepada siswa. Evaluasi pembelajaran berjumlah 10 soal dengan bentuk essay test. Masing-masing soal diberi skor 10 maka total skor adalah 100. Nilai diperoleh dari jumlah skor perolehan dibagi skor maksimal dikalikan dengan 100.

4. Refleksi meliputi, analisa dari evaluasi pembelajaran yang dilakukan oleh siswa untuk menentukan tindak lanjut yang dilakukan guna pemecahan masalah pembelajaran.

\subsection{Instrumen Penelitian}

Pada Penelitian Tindakan Kelas ini, instrumen yang digunakan berupa:

1. Tes

Instrumen tes digunakan untuk menjaring hasil belajar siswa

2. Angket Instrumen angket digunakan untuk menjaring minat siswa tentang strategi pembelajaran kontekstual

3. Observasi

Keaktifan siswa dalam proses kegiatan belajar mengajar Bahasa Inggris dan penerapan Strategi Pembelajaran Peningkatan Kemampuan Berfikir.

\subsection{Teknik Pengumpulan Data}

Teknik pengumpulan data yang digunakan dalam penelitian ini adalah menggunakan: (1) angket, (2) tes dan (3) observasi. Angket digunakan untuk mengumpulkan data tentang minat siswa, kemudian tes digunakan untuk menjaring data siswa, kemudian tes digunakan untuk menjaring data tentang hasil belajar siswa dan observasi digunakan untuk menjaring data tentang keaktifan siswa dalam proses belajar mengajar.

\subsection{Teknik Analisa Data}

Teknik analisis data yang digunakan adalah menggunakan jumlah nilai rata rata siswa, persentase jumlah siswa yang tuntas dan persentase jumlah siswa yang belum tuntas.

\subsection{Indikator Kinerja}

Adapun indikator kinerja dalam penelitian ini adalah jika $80 \%$ siswa memperoleh nilai sama dengan 70 atau lebih dan $80 \%$ siswa aktif dalam kegiatan belajar mengajar, maka penelitian sudah jenuh sehingga tak perlu dilanjutkan ke siklus berikutnya. 


\section{HASIL DAN PEMBAHASAN}

\subsection{Pembahasan Penelitian}

Berdasarkan data hasil belajar siswa, penerapan Strategi Pembelajaran Peningkatan Kemampuan Berfikir dapat meningkatkan hasil belajar siswa. Hal ini dapat dilihat dari hasil belajar siswa pada siklus I dan siklus II berikut:

1. Terdapat peningkatan rata-rata hasil belajar siswa, dimana pada tes awal rata-rata hasil belajar siswa adalah 39, pada siklus I meningkatkan menjadi 67,5 kemudian pada siklus II meningkat lagi menjadi 77,81 .

2. Terdapat peningkatan jumlah siswa yang tuntas, dimana pada tes awal jumlah siswa yang tuntas hanya $0 \%$, meningkat menjadi $75,0 \%$ pada siklus I kemudian meningkat lagi menjadi $87,5 \%$ pada siklus II

3. Terdapat penurunan jumlah siswa yang tidak tuntas, dimana pada tes awal jumlah siswa yang tidak tuntas mencapai $100 \%$, pada siklus I menurun menjadi $25,0 \%$ kemudian pada siklus II menurun lagi menjadi $12,5 \%$ dengan kata lain hanya 4 siswa saja yang memperoleh nilai 60 dan selebihnya (28) siswa memperoleh nilai di atas 70 . Hal tersebut di atas dapat dilihat pada diagram di bawah ini:

\section{Diagram 4.4}

Hasil Belajar, Tes Awal, Siklus I, Siklus

II

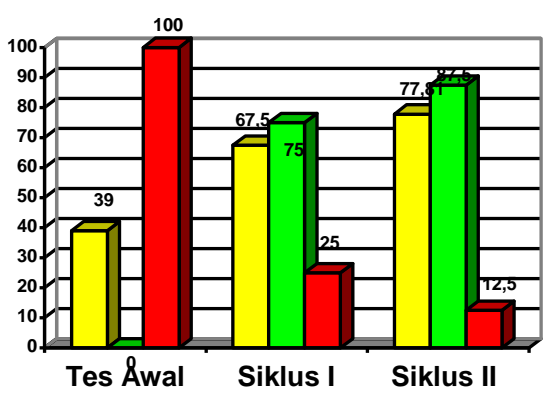

Keterangan:

Kuning $\square=$ Rata-rata $\begin{array}{ll}\text { Hijau } & =\text { Tuntas } \\ \text { Merah } \square=\text { Tidak Tuntas } & \square\end{array}$

\section{KESIMPULAN}

Berdasarkan data hasil belajar siswa, penerapan strategi pembelajaran berbasis masalah maka dapat disimpulkan bahwa:

1. Terdapat peningkatan rata-rata hasil belajar siswa, dimana pada tes awal rata-rata hasil belajar siswa adalah 39 , pada siklus I meningkatkan menjadi 67,5 kemudian pada siklus II meningkat lagi menjadi 100 .

2. Terdapat peningkatan jumlah siswa yang tuntas, dimana pada tes awal jumlah siswa yang tuntas hanya $0 \%$, meningkat menjadi $75,0 \%$ pada siklus I kemudian meningkat lagi menjadi $87,5 \%$ pada siklus II

3. Terdapat penurunan jumlah siswa yang tidak tuntas, dimana pada tes awal jumlah siswa yang tidak tuntas mencapai $100 \%$, pada siklus I menurun menjadi 25,0\% kemudian pada siklus II menurun lagi menjadi $12,5 \%$ dengan kata lain hanya 4 siswa saja yang memperoleh nilai 60 dan selebihnya (28) siswa memperoleh nilai di atas 70 .

\section{DAFTAR PUSTAKA}

Hamalik, Oemar. (2006). Proses Belajar Mengajar. Jakarta: Bumi Aksara

Hamdani. (2011). Metode Belajar Mengajar. Bandung : Pustaka Setia

Ibrahim dan Nur. (2000). Strategi Pembelajaran. Jakarta : Bumi Aksara

Sanjaya, Wina. (2011). Metode Pembelajaran Berorientasi Standar Proses Pendidikan. Jakarta: Kharisma Putra Utama.

Sudjana, Nana. (2010). Penilaian Hasil Proses Belajar Mengajar. (Cet. XV). Bandung: Remaja RoSMPa Karya

Sugandi, A. (2004). Teori Pembelajaran. Semarang: UPT MKK Universitas Negeri

Malang. 